\title{
Participation in International Telecommunication Projects for Intercultural Communication and Creating an English Authentic Environment Development
}

\section{Kalizhanova, Anna ${ }^{a}$; Ibrayeva, Bayan $^{\mathrm{b}}$ and Ishmuratova, Margarita}

${ }^{a}$ Foreign Languages and Intercultural Communication Department, Bolashak Academy, Kazakhstan, ${ }^{\mathrm{b}}$ Foreign Languages and Intercultural Communication Department, Bolashak Academy, Kazakhstan, ${ }^{\mathrm{c}}$ Botany Department, Karaganda State University named after academician Ye.A. Buke

\begin{abstract}
This article describes the experience of participation in one international telecommunication project My City and Me, conducted by the U.S. International Education and Resource Network (iEARN) that united 26,000 teachers, around 2,000,000 students from 140 countries for working on 3,000 projects in 30 different languages. The described project aimed to foster ESL learner' awareness of intercultural communication. Moreover, the Project participants learned how to choose the right technologies and software and create an authentic English environment.
\end{abstract}

Keywords: IEARN, information and communication technologies, communicative skills, authentic environment. 


\section{Introduction}

Nowadays, the Kazakhstani government sets such objectives as upbringing and creating a communicative and competent specialist that will manage to represent the country in the world arena with all dignity and respect ("UNDP in Kazakhstan" 2004). A national educational project "The Trinity of Languages" aims for the increasing the role of Kazakh language as a state one, accepting the high significance of Russian language and developing favorable conditions to master English language (Seitzhanova 1970). However, Kazakhstan still faces many issues connected with the lack of English native speakers due to the latter unwillingness to work in the far and unknown place, the impression about which is full of stereotypes and prejudices ("Teach English in Kazakhstan").

Another issue regarding the contemporary educational process involves the demand for teachers to use a lot of software equipment, which does not mean a high quality of performance and assimilation of the material. The choice of any software should be justified and appropriate, so that information and communication technologies help in solving specific problems. In other words, techniques should not dominate in the educational process. According to Varshuer and Hailey (1998), the goal of any software should involve learning experience in the development of authentic and communicative environment with the help of multimedia tools by a thorough evaluation of any programs to meet personal and professional needs of students.

In this regard, the ESL teachers of the Private Institution Bolashak Academy decided to participate in the international, telecommunication project My City and $M e$, held by the International Education and Resource Network (iEARN). This organization unites 26,000 teachers and around 2,000,000 students from 140 countries for working on 3,000 projects in 30 different languages (IEARN Collaboration Centre). Since 1998, the slogan of iEARN is "Linking Communities to Make a Difference in the World" (IEARN Collaboration Centre). iEARN involves students from different corners of the Earth in network project work and provides a platform for publishing their projects' results and sharing experiences. iEARN grants students an opportunity to organize a variety of conferences or projects individually within the sphere of suggested topics with the help of information and communication technologies.

The choice of the project My City and Me was justified by the students' desire to promote their hometown Karaganda in Kazakhstan, familiar for the most only thanks to the song by pop-band Dune. The Project aimed at creating vitally crucial for Kazakhstani ESL students an authentic English-speaking environment as well as building necessary for safe and peaceful coexistence in the modern world awareness of the intercultural communication skills. Additionally, the $1^{\text {st }}$-year ESL students were supposed to learn to choose the right 
software and information and communication technologies for successful implementation of the Project.

\section{Objectives and Methods}

The experiment involved four $1^{\text {st }}$ grade students of the specialty "Foreign Language: Two Foreign Languages" of the Department of Foreign Language and Intercultural Communication and lasted from December to April 2017.

The quantitative and qualitative research methods, as well as data analysis and processing, were defined to complete the Project.

\section{The Flow of the Experiment}

\subsection{Stage 1}

The project was subdivided into several phases. The first step included brainstorming, choosing appropriate informative and communicative technologies, identifying the scope of workflow, and delegating tasks. The Bolashak Academy students decided to use Trello Board - a free online platform that was highly popular among IT engineers in their projects implementation.

Additionally, with the help of Google forms, the students surveyed Karaganda $11^{\text {th }}$-grade graduates' opinions about all pros and cons of living in Karaganda as well as either staying or leaving the city based on the town's potential for personal and professional development.

\subsubsection{Survey Data Processing}

The six-question survey allowed to receive the answers of one hundred and twenty $11^{\text {th }}$ grade students of different schools in Karaganda.

$52.5 \%$ of respondents answered positively on the first question "Do you think Karaganda is a good place for living?", whereas $45 \%$ of respondents answered negatively, but $2.5 \%$ ones chose the option "it is hard to answer."

The second question "How do you think are there more advantages or disadvantages of living in Karaganda?" indicated $60 \%$ of surveyed who could see only disadvantages whereas the rest $40 \%$ voted for advantages.

The third question revealed Karaganda teens' favorite places: Central Park (29.1\%), shopping centers $(4.1 \%)$, some cafés and fast-food restaurants $(35.7 \%)$, cultural sites $(21.6 \%)$, theatres, cinemas $(6.5 \%)$, and no favorite place $(16.6 \%)$.

$76.6 \%$ of respondents showed their willingness to leave Karaganda when answering the fourth question "Are you planning to stay in Karaganda or leave in another city/country after graduating?" Only $23.3 \%$ of future graduates thought to stay in their hometown. 
The fifth question "Could you advice foreign residents or citizen of our country, who live in other cities to visit Karaganda city?" showed that $53.3 \%$ of youngsters would approve the arrival of foreigners in Karaganda, while $44.16 \%$ of surveyed would not recommend visiting this city.

The last sixth question asked the future school graduates to estimate the level of lifestyle in Karaganda from 1-10 and resulted in 57.5\% of surveyed, who gave lower than 5 points. Also, $16.6 \%$ of future graduating students gave Karaganda 5 points, whereas, surprisingly, $25.8 \%$ of respondents rated Karaganda higher than 5.

\subsubsection{Survey Results}

On the whole, more than $50 \%$ of young people dreamed of leaving Karaganda after graduating because they could see no perspectives for a future career path and professional development. Moreover, the surveyed teenagers named such favorite places as Central Park, City Mall, and some cafés but not museums or theatres for leisure-time and cultural activities in the city. Thus, the conducted survey results defined the second stage of the project that included the presentation of Karaganda in the form of a virtual tour around Karaganda's universities with the help of Windows Image Composite software to reflect the high academic and creative potential.

\subsection{Stage 2}

Instead of ordinary presentations made in PowerPoint by the majority of the iEARN participants from different countries, the students of the Private Institution Bolashak Academy decided to create English comics, where they would show the most beautiful places of Karaganda in the image of the comics' characters (see figure 1).
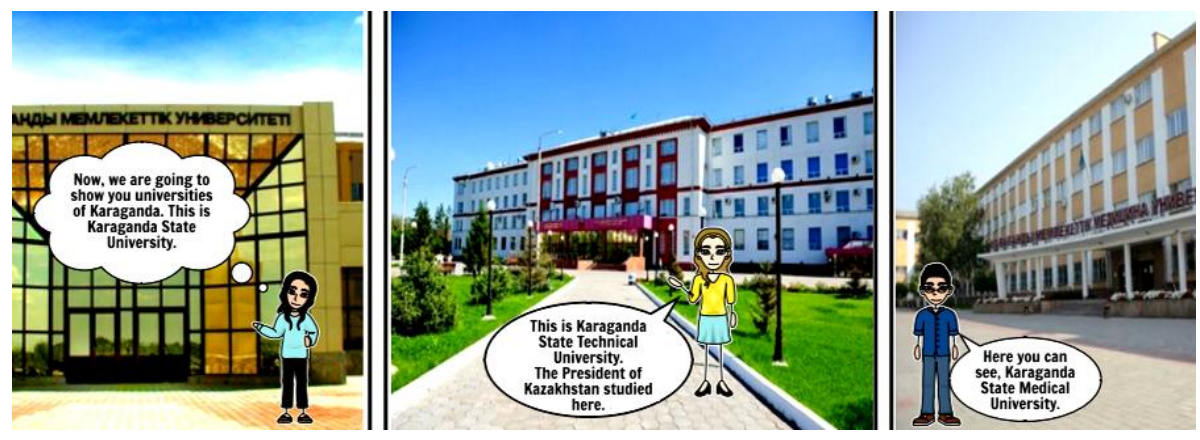

Figure 1 demonstrates some slides from the cartoons made by the students of Bolashak Academy to present the universities of Karaganda City. 
For that purpose, Bolashak students chose the program StoryBoardThat (The World's Best Free Online Storyboard Creator). Such a fresh solution on Karaganda City presentation met the approval of the participants from different countries and was recognized as the most unusual and exciting.

\subsection{Stage 3}

The next phase involved the students of Bolashak Academy in collaboration with other countries' participants for the joint international project creation and required to choose one of the proposed by the organizer's topics and become rated by the age. In the pursuit of the friendship with the native English speakers and exchange of intercultural values, the students of Bolashak Academy joined the USA team. At the same time, the students of Bolashak Academy extensively commented and supported participants from Russia, China, Egypt, Turkey and many other countries, which got less attention compared to the participants from Canada, England, or the USA. The students from Karaganda could successfully create an authentic English-speaking environment and established a friendly connection with age mates from different countries via Skype and Facebook.

\section{4. iEARN Project Participation Analysis}

The iEARN project My City and Me allowed its participants from Karaganda to contribute equally and proportionately to their possibilities and interests. In particular, skilled in photography student was responsible for taking panoramic pictures and creating a virtual tour around Karaganda. Another student, interested in poetry, wrote small poems about Karaganda for the comics. The students with the dominant interpersonal intelligence (Gardner 1983) was in charge of timely contacting and responding to the participants from other countries via Skype or Facebook. The $4^{\text {th }}$ student was responsible for attaching all Project products to Trello Board. In all, such a mutual collaboration made such participation rewarding and fruitful. Furthermore, the students limited and combined the number of technologies for achieving the project goals.

Bolashak Academy students highly estimated the experience of participation in the Project My City and Me, held by iEARN, and pointed out the tremendous benefit of the further use of technologies, active communication with non and English speaking participants, and the development of virtual tour and comics. The Project demonstrated that the appropriate goal setting outlined right strategies and techniques to develop useful products and contacts for students in further personal and professional development.

\subsection{Advantages}

Analyzing strengths and weaknesses of participation in international telecommunication project iEARN, the advantages entirely are: 
1. the rise of the social significance of students by participating in international telecommunication projects;

2. getting to know the process of the global project from planning all stages and setting goals to the successful realization of the plan;

3. extension of the students' intercultural awareness and leadership skills, such as initiatives, synthesis, analysis, collaboration;

4. an additional English-speaking environment's creation by establishing the connection with natives speakers that increased the participants' English proficiency level;

5. the reasonable choice of technologies, appropriately adjusted to the project's each stage's need;

6. maintaining the level of motivation for learning English through the realization of its importance for intercultural communication and further development in the professional and personal life;

7. education of patriotism and love to the hometown and the motherland

\subsection{Disadvantages of the Project}

It is necessary to mention following disadvantages, typical for such projects:

1. dependence on external factors, such as a timeless response to comments and messages by other project participants;

2. biased attitude to the students from not English-speaking countries, such as Egypt or Bangladesh, caused by too extensive attention to English native speakers;

3. lack of the possibility to establish a full connection with other participants within the only iEARN platform; further communication with other participants can switch to the social networks or Skype upon an initiative of participants;

4. irrational time-management, assigned to different stages of the project;

5. short life-cycle of such projects due to lack of confidence in further joint work during the whole project workflow;

6. lack of consistent and regular engagement of participants from different countries in the project: English speaking countries' participants rarely and weakly connected to the developing countries, dominated by the substantial quantitative overbalance. 


\section{Conclusion}

Summing up, positive impressions from the participation in iEARN Project My City and $M$ e outweighed the drawbacks and allowed concluding that involvement in similar projects develops intercultural communication skills and improves English language knowledge. Moreover, such projects form cultural and social, linguistic, and communicative competences, removes the linguistic barrier, creates an authentic English environment, and develops research, organizational, and leadership skills. Finally, taking part in international telecommunication projects raises social significance and helps fulfill the creative potential of each project participant. In conclusion, the participation in the global scheme on the iEARN platform sufficiently changes the script "education-learning," broadens the scientific and intercultural horizons and goes beyond the bounds of a particular city and even the country.

\section{References}

Gardner, H. (1983). Frames of Mind: The Theory of Multiple Intelligences. New York: Basic Books.

iEARN Collaboration Centre. (n.d.). Retrieved January 24, 2018, from https://iearn.org/

Seitzhanova, A. et al. (1970). New Trend of Education in Kazakhstan: English as the Medium of Instruction. Retrieved from https://econpapers.repec.org/RePEc:pdc:jrpieb:v:15:y:2015:i:3:p:113-116

Teach English in Kazakhstan | Information for English teachers. (n.d.). Retrieved from http://www.eslbase.com/countries/teach-english-in-kazakhstan

The World's Best Free Online Storyboard Creator. (n.d.). Retrieved January 24, 2018, from http://www.storyboardthat.com/

UNDP in Kazakhstan. (2004). Retrieved from http://www.kz.undp.org/

Warschauer, M., \& Healey, D. (1998). Computers and Language Learning: An Overview. Language Teaching, 31(02), 57. doi:10.1017/s0261444800012970 